\title{
PERSPEKTIF FIKIH EKONOMI TERHADAP PELAKSANAAN AKAD "UTANG PIUTANG" PADA PERBANKAN SYARIAH DI SUMATERA BARAT
}

\author{
Syukri Iska \\ Program Pascasarjana STAIN Batusangkar \\ Jl. Jenderal Sudirman No. 137, Lima Kaum Batusangkar \\ e-mail: syukri.iska@yahoo.co.id
}

\begin{abstract}
This study was purposed at identifying the various transactions in Islamic banking of West Sumatera were categorized on the "debts"; describing the implementation of the transaction; and analyzing the various transactions were based on the economic fiqh perspective. This study belongs to qualitative case study by using in-depth interviews as research instrument. The data were analyzed qualitatively based on the economic fiqh perspective, Al-Qur'an, Sunnah, Ijtibad the scholars, and the Fatwa of National Sharia Council (DSN) and Indonesian Council of Scholars (MUI). The results of this study revealed that the types of transactions were categorized "debts" was murabahah, qardh (bailout pilgrimage), biwalah, and rabn (pawning gold). Murabahah was presented on all Islamic Bank but not all transactions on Islamic banking of West Sumatera based on the economic figh perspective such the calculation of the margin murabahab based on the amount of banks financing. Then the calculation of ujrah on the bailout pilgrimage was still based on the amount of bail. Furthermore, the calculation of ujrah on pawning gold was not based on the calculation of the treatment period but to the amount of "debt" funds. The conclusion was the implementation of the "debts" contract in Islamic banking of West Sumatera not run well as the economic fiqh perspective.
\end{abstract}

Kata kunci: akad "utang piutang", perpektif fikih ekonomi, perbankan syariah, Sumatera

Barat

\section{PENDAHULUAN}

O

ntuk di Indonesia saat ini, pertumbuhan dan perkembangan bank umum syariah telah mengalami peningkatan yang signifikan. Kalau dilihat pada saat awal berdirinya bank syariah di Indonesia pada awal tahun 90-an, baru 1 (satu) yakni Bank Muamalat Indonesia (BMI) saja. Namun saat ini bank umum syariah telah mencapai 11 (sebelas) unit, seperti Bank Syariah Mandiri (BSM), Bank Rakyat Indonesia (BRI) Syariah, Bank Negara Indonesia (BNI) Syariah, 23 (dua puluh tiga) bank unit usaha syariah, dan beratus-ratus lembaga keuangan syariah mikro, seperti Bank Pembiayaan Rakyat Syariah (BPRS) (Direktorat Perbankan Syariah Bank Indonesia, Outlook Perbankan Syariah Indonesia, 2011).

Perkembangan perbankan syariah tersebut juga terlihat di Sumatera Barat, yang ditandai dengan berdirinya 5 Kantor Cabang Bank Umum Syariah; Bank Muamalat Indonesia (BMI), Bank BNI Syariah, Bank BRI Syariah, Bank Syariah Mandiri (BSM), dan Bank Bukopin Syariah. Namun bank yang 
dimiliki sepenuhnya oleh masyarakat Sumatera Barat yakni Bank Nagari, belum lagi berwujud Bank Umum Syariah, melainkan baru berbentuk bank konvensional yang memiliki unit usaha syariah. Pertumbuhan asset perbankan syariah di Propinsi ini per triwulan III tahun 2011 telah mencapai 2,48 triliun rupiah, naik $65,8 \%$ dibandingkan tahun 2010.

Pertumbuhan dan perkembangan tersebut, di antaranya dipengaruhi oleh keberagaman dan inovasi produk dari perbankan syariah itu sendiri. Kalau pada awal-awal berdirinya perbankan syariah ini, jenis produk yang ada baru sebatas Mudharabah dan Murabahah. Akan tetapi saat ini lebih variatif, seperti Musyarakah Mutanaqishah, Hawalah, Rahn, Qardh, yang mengundang kajian dan akhirnya menimbulkan berbagai perspektif, terutama dalam bidang kajian keabsahan dalam perspertif fikih ekonomi (hukum Islam).

Munculnya stigma miring terhadap perbankan syariah saat ini, yakni tidak lebih dari sekedar bank konvensional berganti "baju" bank syariah, telah memberikan pengaruh belum begitu sepenuhnya dapat menyakini sebagian besar umat Islam untuk bisa beralih kepada bank syariah. Apalagi akibat berbagai improvisasi dan kreasi pihak perbankan syariah dalam melahirkan produk, cenderung dipengaruhi oleh benchmark kepada bank konvensional dan tuntutan bisnis, sehingga dalam penerapannya nyaris mengabaikan aspek kesyariahan ini.

Di antara produk yang berpotensi untuk diperdebatkan itu adalah Hawalah (take over credit) bagi nasabah yang memiliki kredit di perbankan konvensional, namun ingin mengalihkannya ke bank syariah. Ijarah Muntahiya bi Tamlik (Lease with Purchase Option), yakni transaksi sewa yang berakhir dengan kepemilikan. Padahal pemahaman tentang Ijarah selama ini hanya sebatas transaksi pemindahan hak guna atas barang dan jasa, melalui pembayaran upah/sewa, tanpa diikuti dengan pemindahan kepemilikan atas barang tersebut (Sayyid Sabiq, 1987: 147).

Demikian juga halnya, selama ini yang dipahami atau diberi pemahaman oleh berbagai literatur, bahwa di antara yang membedakan antara bank konvensional dengan bank syariah adalah bank syariah tidak mengenal hubungan antara nasabah dengan bank sebagai kreditor dan debitor, bagaikan yang ada pada bank konvensional (Kamal Khir, dkk., 2008: 11). Akan tetapi, saat dilihat adanya varian produk di perbankan syariah tersebut, yang bernama Murabahah (jual beli dengan pembayaran angsur), Qardh (Soft and Benevolent Loan), Rahn (Mortgage), atau Gadai, misalnya, yang corak transaksinya adalah "utang piutang", apakah itu tidak dalam konteks kreditor dan debitor?

Dari beberapa persoalan di atas, telah memancing keinginan peneliti untuk meneliti lebih jauh bagaimana pelaksanaan beberapa produk yang bercorak "utang piutang" tersebut di perbankan syariah, khusus yang ada di Sumatera Barat, untuk ditelaah dalam kajian dan kaedah fikih ekonomi.

\section{METODE PENELITIAN}

Jenis penelitian ini adalah field research, yakni penelitian yang semua data didapatkan di lapangan, dan berbentuk deskriptif komparatif di antara perbankan syariah yang ada.

Dalam penelitian ini yang menjadi objek/lapangan penelitian adalah beberapa Bank Umum Syariah (BUS), dan Bank Umum yang mempunyai unit usaha syariah 
yang memiliki kantor cabang di Sumatera Barat.

Datanya didapatkan melalui indepth interview terhadap Pimpinan Cabang atau representasi yang ditunjuk, nasabah dengan teknik snow ball sampling, dan dokumentasi.

Semua data yang didapatkan dalam penelitian ini akan dianalisis secara kualitatif, dibandingkan di antara skim-skim "utang piutang" yang ada pada masing-masing perbankan tersebut dan setelah itu dianalisis lebih jauh berdasarkan perspektif Fikih Ekonomi, sebagaimana yang tertuang dalam al-Qur'an, Sunnah dan kitab-kitab fikih dan atau fatwa.

\section{HASIL PENELITIAN}

\section{Jenis dan Pelaksanaan Akad "Utang Piutang" di Perbankan Syariah}

Hasil penelitian pada objek penelitian, dapat digambarkan jenis dan pelaksanaan akad "utang piutang" sebagai berikut:

\section{Murabahah.}

Pelaksanaan transaksi yang berbentuk jual beli ini, terdapat perbedaan di antara bank-bank tersebut, kendati sama-sama lebih memperuntukkan jual beli rumah atau kendaraan, dan dilaksanakan dengan teknik perwakilan (wakalah) dari bank kepada nasabah untuk pembelian barang kepada distributor, sebelum akad murabahah dilaksanakan.

Pada satu Bank Umum Syariah (Wawancara dengan Zulveri, Representasi BUS, pada 19 Oktober
2012), transaksi murabahah ini, sebagaimana diilustrasikan oleh responden dalam jual beli rumah, misalnya harga rumah Rp. 125.000.000,- dengan margin yang disepakati $50 \%$ untuk masa pembayaran angsuran 5 tahun (Rp. 62.500.000,-). Sehingga Bank ini akan menjual kepada nasabah senilai $R p$. 125.000.000,- + Rp. 62.500.000,- = Rp. 187.500.000,-. Karena Bank mengharuskan nasabah membayar urbun, dalam hal ini misalnya Rp. 50.000.000,-, sehingga jumlah angsuran menjadi Rp. 187.500.000,- Rp. 50.000.000,- = Rp. 137.500.000,yang diangsur selama 5 tahun.

Ilustrasi yang disampaikan
oleh responden berdasarkan wawancara tersebut berbeda dengan data empirik, transaksi tahun 2010 oleh Nasabah X, (Wawancara dengan nasabah $X$ pada, 20 Oktober 2012) yakni pada kasus pembelian sebuah mobil. Harga mobil pada tingkat distributor Rp. 225 juta dan urbun dari nasabah sebesar Rp. 125 juta, sehingga besar pembiayaan oleh Bank senilai Rp. 100 juta. Setelah itu Bank memperhitungkan margin kepada nilai pembiayaan Bank, yakni $50 \%$ (untuk 5 tahun) $x$ Rp. 100 juta $=$ Rp. 50 juta. Sehingga besar transaksi murabahah mobil tersebut Rp. 150 juta yang diangsur selama 5 tahun. Dalam hal ini terlihat bahwa nilai transaksi murabahah mobil tidak sama dengan harga mobil di distributor.

Pelaksanaan akad murabahah pada BUS lainnya (Wawancara dengan Fitra Nirwan, Representasi BUS, pada 11 September 2012) dengan pembiayaan Hunian Syariah 
dan Pembelian Kendaraan. Dalam hal ini nasabah diharuskan membayar urbun sebesar $30 \%$ dari harga rumah atau kendaraan pada distributor. Setelah itu Bank akan memperhitungkan margin dari jumlah pembiayaan $(70 \%$ dari harga barang pada distributor), berdasarkan lama angsuran (untuk rumah biasanya 15 tahun dan kendaraan biasanya 5 tahun).

Demikian juga halnya pelaksanaan murabahah pada beberapa BUS lainnya (Wawancara dengan Wawan, Representasi BUS, pada 11 September 2012) pada pembiayaan Kepemilikan Rumah Syariah, Pembelian Kendaraan dan Kepemilikan Logam Mulia (Wawancara dengan Elvi Irawati, Representasi BUS, pada 2 Oktober 2012 ), yakni sama-sama memperhitungkan margin kepada jumlah pembiayaan bank setelah harga barang di distributor dikurangi urbun, yang wajib dibayarkan oleh nasabah.

\section{Qardh}

Pelaksanaan akad ini di perbankan syariah pada objek penelitian, lazimnya terdapat dalam skim talangan haji. Sehingga cukup dalam masalah ini saja yang menjadi sorotan oleh peneliti.

Pada salah satu BUS, besar talangan hanya satu jenis, yakni sebesar Rp. 22.500.000,- dan kekurangan dana setoran untuk memperoleh nomor porsi haji (Rp. 25 juta), sebesar Rp. 2.500.000,disetorkan oleh nasabah kepada bank, dan selanjutnya bank akan mendaftarkan yang bersangkutan ke Panitia Penyelenggara di Kemenag RI melalui Sistem Komputerisasi
Haji Terpadu (Siskohat). Akibat dari jasa pengurusan pendaftaran dan proses administrasi penggantian uang talangan tersebut oleh nasabah, bank telah memungut uang ujrah atau fee dari nasabah, yang besarnya dipengaruhi oleh masa pelunasan, yakni Rp. 2.850.000,- untuk satu tahun, dan maksimal selama tiga tahun. Selain pembayaran ujrah tidak ada lagi tambahan biaya administrasi, bagaikan pada bank lainnya.

Telah terjadi perubahan dibandingkan data empirik, bahwa setidaknya pada tahun 2010, jenis talangan ada tiga kategori, yakni Rp. 10 juta, Rp. 15 juta, atau Rp. 18 juta. Kendati untuk waktu yang sama, yakni 2 tahun, namun berbeda nilai ujrah yang dipungut karena berbedanya nilai talangan. Artinya, semakin banyak nilai talangan oleh bank, semakin bertambah ujrah yang dibebankan kepada nasabah.

Berbeda pelaksanaannya pada BUS lainnya, yakni dari Rp. 23.750.000,- dana talangan, Bank memungut ujrah sebesar Rp. 10.093.750,- untuk masa pelunasan hanya satu bentuk, yakni 5 tahun (60 bulan), dan ditambah dengan dana administrasi (dibedakannya dengan ujrah) sebesar $1 \%$ dari pembiayaan talangan. Namun sama dengan BSM dari sisi jenis talangannya, yaitu sama-sama satu jenis.

Pelaksanaan akad ini pada BUS lainnya lagi (Wawancara dengan Defrianta Sukirman, Representasi BUS, pada 14 September 2012) pun berbeda dengan bank sebelumnya, yakni ujrah yang dipungut sebesar Rp. 300 ribu, nilai urbun $30 \%$ dari total pembiayaan talangan dan harus 
dilunasi paling lambat dalam waktu satu tahun.

Adapun pelaksanaan akad Qardh untuk talangan haji ini pada BUS yang lain, nasabah harus menyetorkan dananya ke Bank minimal Rp. 5.000.000,-, yang terdiri dari Saldo Mengendap Minimal Rp. 2.000.000,-, Biaya Administrasi (tidak menyebutnya dengan ujrah) Rp. 2.500.000,- dan Pengambilan Porsi Rp. 500.000,-. Jumlah talangan minimal Rp, 11.000.000,- dan maksimal Rp. 24.500.000,-, dengan masa pembayaran atau angsuran maksimal 24 bulan (2 tahun). Artinya, terlihat bahwa perbedaan waktu dan besar talangan, tidak mempengaruhi besar biaya administrasi.

\section{Hiwalah: Akad peralihan utang (take over credit)}

Pada salah satu BUS, (Wawancara dengan responden yang sama pada 12 September 2012) pelaksanaan akad ini ada dalam dua bentuk; pertama, kalau peralihan utang itu dari bank syariah yang lain, pengajuan akad hiwalah oleh nasabah cenderung ditolak, karena sulitnya merumuskan akad pengganti setelah utang tersebut diambil alih oleh BUS tersebut. Biasanya utang nasabah tersebut pada bank syariah lain, dengan memakai murabahah. Artinya telah ada sesuatu objek yang diakadkan dalam bentuk jual beli. Tentunya tidak akan mungkin diakadkan lagi dalam bentuk akad jual beli pada objek yang sama.

Lain halnya kalau peralihan
utang nasabah dari bank

konvensional. Kalau utang pada bank konvensional sebelumnya itu diperuntukkan membeli suatu barang, maka setelah sisa utang nasabah dilunasi oleh Bank dengan akad hiwalah, jenis akad selanjutnya antara nasabah dengan Bank adalah akad murabahah, yakni jual beli pada barang tersebut. Berbeda halnya kalau utang nasabah pada bank konvensional tersebut tidak jelas diperuntukkan untuk apa, maka permohonan hiwalah pada Bank ditolak.

Adapun pelaksanaan akad hiwalah pada BUS lainnya, memiliki kesamaan dengan BUS sebelumnya. Sejauh yang disampaikan oleh responden bahwa akad ini berlaku pada nasabah yang memiliki utang pada bank konvensional. Itupun dalam bentuk utang yang diperuntukkan dahulunya membeli barang. Sehingga bisa dilakukan akad murabahah pada barang yang dibeli dengan uang berbentuk utang pada bank konvensional tersebut.

Sedangkan di BUS yang lain lagi, kendati data yang didapatkan tidak begitu maksimal, akibat teknis, pelaksanaan skim hiwalah ini terlihat agak dibatasi, yakni besarnya pembiayaannya minimal Rp. 200 juta, dan akad tindak lanjut adalah murabahah untuk pembiayaan kepemilikan rumah dan kendaraan saja, kendati ada juga dalam bentuk akad musyarakah untuk pembiayaan modal kerja, yang tidak dimiliki oleh bank lainnya.

\section{Gadai Emas.}

Skim ini tidak dilaksanakan oleh semua bank yang menjadi objek 
penelitian, dengan alasan, bahwa gadai emas ini tidak membuat nasabah menjadi seseorang yang produktif, karena cenderung meminjam dana untuk konsumtif.

Adapun pelaksanaan skim Gadai Emas ini pada salah satu BUS, (Wawancara dengan responden yang sama pada 05 Oktober 2012) berdasarkan informasi dari responden, bahwa pada skim ini terdapat 3 jenis akad; pertama Qardh, yaitu Bank meminjamkan uang atas dasar emas yang telah digadaikan oleh nasabah. Kedua, Rahn, yaitu emas yang digadaikan oleh nasabah kepada Bank. Ketiga, Ujrah, yaitu Bank mendapatkan fee atau upah atas jasa Bank menyimpan dan merawat emas nasabah yang digadaikan tersebut sampai waktu pelunasan utang oleh nasabah.

Dalam gadai ini, Bank memberikan piutang sebesar maksimal $90 \%$ dari harga emas yang digadaikan dalam waktu yang ditetapkan oleh Bank selama 4 bulan, dengan besar ujrah yang ditetapkan Rp. 500 per hari. Seandainya nasabah belum bisa membayar utang pada akhir bulan keempat tersebut, maka masanya bisa diperpanjang lagi, dengan biaya ujrah sesuai dengan ketentuan sebelumnya. Kalau sekiranya, harga emas naik sewaktu perpanjangan waktu tersebut, nasabah boleh menambah pembiayaan qardh.

Akan tetapi, seandainya nasabah masih juga tidak sanggup membayar utangnya pada saat jatuh tempo, kendati telah mengalami perpanjangan waktu, maka Bank berhak mengeksekusi barang gadaian. Kalau nilai emas lebih tinggi dibandingkan nilai utang, maka Bank wajib mengembalikan kelebihannya. Bagaikan juga, kalau sekiranya harga emas turun atau lebih rendah, maka nasabah berkewajiban menutup kekurangan tersebut.

Kalau dilihat dari sisi akad yang dipakai, sama saja pada beberapa BUS tersebut, yakni samasama memakai akad Qardh (utang piutang), Rahn (gadai, dalam hal ini emas), dan Ijarah/ Ujrah (jasa titipan atau perawatan emas yang dilakukan oleh Bank). Akan tetapi cara perhitungan jasa/biaya titipan yang diperhitungkan menjadi pendapatan bank, ada yang memperhitungkannya sebesar 1,25\% dari besarnya pembiayaan (piutang).

\section{Perspektif Fikih Ekonomi tentang Pelaksanaan Akad "Utang Piutang" di Perbankan Syariah}

\section{Murabahah}

Seluruh responden pada setiap bank syariah yang diteliti menyatakan bahwa dalam pelaksanaan akad ini, terlebih dahulu diawali dengan akad wakalah, yakni pihak bank mewakilkan kepada nasabah untuk bertransaksi dengan dengan pihak distributor barang. Akad wakalah pada posisi ini merupakan konsekuensi logis dari bank bukanlah distributor terhadap barang yang dijual tersebut. Karena keterbatasan teknis, pihak bank tidak akan mungkin untuk selalu bertransaksi secara langsung dengan distributor, atau pihak nasabah bisa lebih leluasa memilih barang langsung ke tempat distributor. Untuk itu, suatu hal yang seharusnya, pihak bank mewakilkan kepada nasabah atas nama bank 
(wakalah), untuk melakukan transaksi dengan distributor.

Kalau dianalisis menurut perspektif Fikih Ekonomi, akad ini telah disyariatkan dalam Islam, karena memberikan nuansa tolong menolong, akibat keterbatasan kemampuan yang dumiliki oleh manusia. Kebolehan akad ini telah digambarkan oleh Allah dalam kisah Nabi Yusuf A.s. yang meminta mandat kepada Rajanya untuk menjadi bendahara:

$$
\text { اجعلني على خزائن الأرض إنى حفيظ عليم }
$$

Jadikanlah aku bendaharawan Negara (Mesir). Sesungguhnya aku ialah orang yang pandai menjaga lagi berpengetahuan. (Q.S. Yusuf [12]: 55)

Dalam Fiqh al-Sunnah, Sayyid Sabiq menyampaikan bahwa Rasulullah Saw pernah mewakilkan kepada Abu Rafi' untuk mewakilinya mengawini Maimunah R.a. Begitu juga halnya, Rasul pernah mewakilkan dalam membayar utang, menetapkan batasan dan mengurus untanya, dan sebagainya kepada sahabat (Sayyid Sabiq, 1971: 299).

Akad wakalah ini telah dilakukan dengan ijab wa qabul yang jelas tertuang dalam naskah tertulis, sebagaimana contoh naskah transaksi pada salah satu BUS. Berarti, cara ini telah sesuai dengan ketentuan Fikih Ekonomi, yakni salah satu rukun wakalah itu harus ada akad ijab wa qabulnya (Sayyid Sabiq, 1971: 230).

Adapun transaksi wakalah ini dilakukan sebelum terlaksananya secara resmi akad murabahah, sebagaimana yang dilakukan oleh semua bank syariah tersebut. Cara seperti itu juga telah sesuai dengan ketentuan Fikih Ekonomi, sebagaimana fatwa Dewan Syariah Nasional Majelis Ulama Indonesia (DSN-MUI) No. 04/DSNMUI/IV/2000, yang menyatakan bahwa jika bank mewakilkan kepada nasabah untuk pembelian barang, akad murabahah harus dilakukan setelah barang secara prinsip menjadi milik bank (Dewan Syariah Nasional MUI, Himpunan Fatwa Dewan Syariah Nasional, 2006)

Sedangkan

mengenai perhitungan margin keuntungan oleh bank, sebagaimana ilustrasi akad murabahah pada jual beli rumah yang dikemukakan oleh BSM, bahwa perhitungannya kepada harga barang di distributor, tentunya tidak ada masalah secara syariah, karena memang seperti itulah hakikat akad murabahah tersebut, yakni jual beli yang disampaikan oleh penjual harga resminya di pasaran dan margin atau keuntungan penjual didasarkan kepada kesepakatan dengan pembeli.

Cara yang dilakukan oleh Bank tersebut seperti itu, berbeda dengan data empirik tahun 2010, yaitu jual beli kendaraan. Pada transaksi ini, Bank memperhitungkan marginnya bukan kepada harga kendaraan di tingkat distributor, melainkan memperhitungkannya kepada besaran pembiayaan (piutang) yang diberikan oleh Bank. Dalam hal ini, tentunya sulit membedakannya dengan cara perhitungan yang dilakukan oleh bank konvensional 
(bunga), karena memperhitungkan kelebihan kepada kredit/pinjaman yang diberikan, yang berarti riba.

Lain halnya kalau Bank memberikan pembiayaan murabahah ini sebesar nilai harga barang di distributor, sebagaimana iluistrasi murabahah rumah di atas. Namun karena dalam transaksi kendaraan tersebut, nasabah (pembeli) dituntut harus menyerahkan uang muka (Urbun/DP), maka besar pembiayaan (piutang) oleh bank tidak lagi sepenuhnya. Cara itu tertuang secara jelas dalam naskah transaksi, bahwa nilai transaksi murabahah tersebut hanya sebatas jumlah antara pembiayaan ditambah dengan margin yang diperhitungkan kepada besar pembiayaan, sebagaimana data empirik yang telah disampaikan di atas.

Akan berbeda halnya, cara perhitungan seperti itu hanya sebatas alat ukur atau benchmark semata, untuk memperlihatkan berapa keuntungan yang diambil oleh bank. Namun dalam transaksi/akad harus dituangkan bahwa harga penjualan berdasarkan akad murabahah adalah harga di distributor ditambah margin (perhitungannya sekian persen dikali besar pembiayaan). Setelah itu baru dituangkan urbun sekian, dan nilai angsuran menjadi sebesar harga penjualan dikurangi urbun. Cara seperti inilah yang lebih sesuai dengan hakikat murabahah dan agar bisa terbedakannya dengan cara perhutungan kelebihan pada transaksi kredit (bunga) pada bank konvensional.

Cara pelaksanaan akad murabahah yang bermasalah bagaikan data empirik tentang jual beli kendaraan tersebut di atas, ternyata juga terdapat pada semua jenis akad murabahah pada bankbank syariah lainnya.

Selanjutnya, berbedanya harga jual beli antara tunai dan angsuran, dalam perspektif fikih klasik, ternyata terdapat perbedaan pendapat di kalangan Imam Mazhhab. Imam Malik, Imam Syafi' i, dan Imam al-Syaiban (Mazhhab Hanafi), tidak membolehkan tingginya harga penjualan kredit, karena tambahan dipengaruhi oleh masa/waktu atau penundaan pembayaran. Hal ini, menurut mereka, tergolong riba (Abdullah Saeed, 1996: 78, 80, 82)

Berbeda halnya dengan pendapat kalangan Mazhhab Maliki, Syafi'i, Hanbali dan Ibn Qayyim, bahwa ketentuan harga kredit lebih tinggi dibandingkan dengan harga tunai, dibolehkan, dengan alasan bahwa; cara seperti itu tidak ada ketentuannya dalam al-Qur'an dan Sunnah, kelebihan tersebut terjadi dalam transaksi jual beli bukan utang piutang, kenaikan telah ditentukan pada saat penjualan, dan lain sebagainya (Syauqi Ismail Syihata, 1987: 104-107).

\section{Qardh}

Qardh khususnya pada talangan haji. Kalau diamati dan dianalisis satu persatu di antara bank syariah yang menjadi objek penelitian, dapat gambaran sebagai berikut:

Pada BUS saat ini, jenis talangan haji hanya satu, namun masa pembayaran dana talangan tersebut ada tiga alternatif; setahun, dua tahun atau tiga tahun. Untuk itu besarnya ujrah, memiliki kelipatan 
sesuai dengan pilihan masa pelunasan oleh nasabah. Artinya, di sini terlihat bahwa besar ujrah dipengaruhi oleh masa pelunasan.

Kalau dianalisis menurut perspektif Fikih Ekonomi ujrah adalah akibat dari jasa yang diberikan oleh bank kepada nasabah. Di antara jasa tersebut adalah pelayanan administrasi yang diberikan setiap waktu nasabah menyerahkan angsuran pelunasan dana talangan tersebut. Jadi, semakin lama masa pembayaran yang dipilih oleh nasabah, semakin sering pelayanan itu diberikan oleh bank. Untuk itu cara seperti itu dibenarkan dalam Islam, karena memberikan ujrah atau upah akibat manfaat atau jasa yang diberikan telah dibenarkan oleh Allah, sebagaimana firman-Nya:

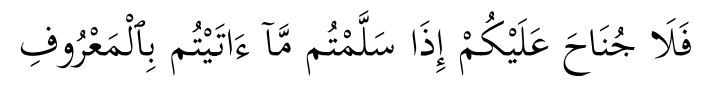

Tidak ada dosa bagimu apabila kamu memberikan pembayaran (jasa, pen.) menurut yang patut." (Q.S. alBaqarah [2] : 233)

Berbeda halnya dengan pelaksanaan talangan haji di Bank, setidaknya pada tahun 2010. Saat itu jenis talangan haji ada tiga kategori yang dapat dipilih oleh nasabah. Namun Bank memperhitungkan ujrah tersebut terhadap besarnya dana talangan tersebut. Artinya semakin besar dana yang ditalangi, semakin besar ujrahnya. Model seperti ini jelas tidak sesuai dengan hakikat akad Ijarah (sewa/pelayanan). Ujrah atau upah adalah akibat dari jasa yang diberikan, bukan dari uang yang dipiutangi. Kalau pengambilan manfaat atau jasa dari akad piutang (qardh), maka ianya tergolong kepada riba, sesuai dengan Hadis (ada ulama yang mengatakan kaedah) yang diriwayatkan oleh alHarits bin Abi Usmah dari Ali:

$$
\text { كل قرض جر منفعة فهو ربا. }
$$

Pada setiap transaksi utang piutang, terjadi pengambilan manfaat, maka hal itu tergolong kepada riba.

Berbeda pelaksanaannya di BUS lainnya, yakni di samping ujrah, pihak Bank juga memungut uang administrasi sebanyak $1 \%$ dari total pembiayaan. Persoalan ini semakin menarik karena adanya dua bentuk penarikan untuk pendapatan Bank, yakni ujrah atau upah dari pelayanan dan biaya administrasi, yang oleh bank syariah lainnya disatukan saja. Dengan demikian perlu adanya kejelasan secara konkrit dalam transaksi apa yang dimaksudkan dengan dua istilah tersebut. Kalau tidak, akan terjadi tumpang tindih pembayaran, kalau uang administrasi juga dimaksudkan sebagai imbalan jasa pelayanan. Kecuali halnya uang administrasi tersebut dimaksudkan untuk biaya proses awal dan ganti rugi terhadap inventaris yang dipergunakan saat itu. Sedangkan ujrah dimaksudkan untuk jasa membantu nasabah dalam pendaftaran ke Siskohat Kemenag RI dan jasa pelayanan pada masa-masa nasabah mengangsur penggantian dana talangan tersebut, yakni selama 5 tahun (60 bulan). 
Kalau dianalisis secara perspektif Fikih Ekonomi, sama saja dengan BUS sebelumnya yakni mengambil upah akibat jasa yang diberikan, dibolehkan dalam Islam, berdasarkan ayat di atas.

Pelaksanaan talangan haji ini pada BUS lainnya lagi, terlihat lebih sederhana. Bentuknya hanya dalam satu kategori, baik dari besar talangan, waktu, dan ujrah-nya. Sehingga tidak ada persoalan kalau diamati berdasarkan Fikih Ekonomi.

Jauh berbeda halnya dengan bentuk talangan haji ini di BUS satunya lagi. Kategori besar talangannya sampai kepada 27 kategori pilihan; mulai dari Rp. 10.500.000,- sampai dengan Rp. 24.500.000,-. Kendati banyak alternatif besaran talangannya, namun biaya administrasi (tidak menamakannya dengan ujrah) tetap sama, yakni Rp. 2.500.000,- dan tempo pembayaran untuk satu, dua, atau tiga tahun.

Cara yang diterapkan oleh BUS sebelumnya ini pun, terlihat tidak ada persoalan secara Fikih Ekonomi, karena nilai ujrah-nya tidak dipengaruhi sedikitpun oleh besar talangan. Bahkan juga tidak dipengaruhi oleh tempo pembayaran, kendati syariah pun tidak akan mempersoalkan kalau seandainya berbeda ujrah karena dipengaruhi oleh berbedanya masa pembayaran, akibat bertambahnya jasa pelayanan yang diberikan.

Terlihat ada persoalan secara Fikih Ekonomi, pelaksanaan talangan haji pada salah satu BUS lainnya. Kendati masa pembayaran itu satu kategori, yakni lima tahun, namun perhitungan ujrahnya dipengaruhi oleh besar talangan.
Artinya, berbedanya jumlah talangan, akan mengakibatkan berbeda pula ujrah yang dibayarkan oleh nasabah. Cara inilah yang memberikan nuansa riba, karena terlihat mengambil manfaat dari nilai utang, sesuai dengan kaedah yang dikemukakan sebelumnya, bukan dari jasa yang diberikan.

\section{Hiwalah.}

Dari dua bank syariah objek penelitian yang melaksanakan skim hiwalah ini, terlihat adanya corak yang beragam.

Pada salah satu BUS, hiwalah atau peralihan utang yang diajukan oleh nasabah dari bank syariah lainnya, ditolak sama sekali, dengan alasan akan terjadi dua kali transaksi jual beli (murabahah) pada objek barang yang sama. Hal ini tentunya tidak sesuai dengan syariah. Perspektif Bank seperti ini, sangat tepat, karena memang salah satu syarat sahnya akad murabahah tidak terjadi transaksi berulang untuk barang yang sama. Bagaimana kalau akad sebelumnya itu bukan murabahah? Bank tidak juga melayani, karena sulit menyarikan skim yang sesuai dengan syariah.

Berbeda halnya kalau hiwalah itu diajukan nasabah, kalau berasal dari utang yang ada pada bank konvensional. Bank melayaninya, kalau utang tersebut diperuntukkan untuk pembelian barang. Sehingga setelah BUS ini mengambil alih utang tersebut, antara Bank dengan nasabah dilakukan transaksi dengan memakai akad murabahah. Akan tetapi seandainya, utang nasabah ke bank konvensional tersebut tidak jelas diperuntukkan untuk 
pembelian barang, maka Bank menolak skim hiwalah ini.

Cara seperti itu memberikan dua sisi pandangan; pertama, menyelamatkan nasabah dari praktek riba karena memakai transaksi bunga. Kedua, skim hiwalah merupakan salah satu bentuk akad yang disyariatkan dalam Islam, sebagaimana sabda Rasulullah Saw yang diriwayatkan oleh Bukhari dan Muslim dari Abi Hurairah (AlKahlani, t.th.: 61):

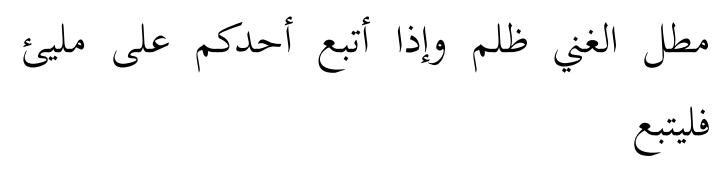

Menunda pembayaran bagi yang mampu ialah zalim. Jika salah seorang kamu diikutkan (dihiwalahkan) kepada orang kaya yang mampu, maka ikutilah.

Menurut Sayyid Sabiq, Hadis ini dimaksudkan bahwa Rasul memerintahkan orang yang berutang menerima hiwalah dari orang kaya, sehingga utangnya dapat dibayar, dengan syarat ada kerelaan dari semua pihak, harus ada kesamaan antara jenis, kadarnya, tempo dan baik buruk objek tersebut, dan utang piutang tersebut harus diketahui dengan jelas (Sayyid Sabiq, 1971: 212-213).

Sedikit berbeda halnya dengan BUS lainnya, melayani skim hiwalah kalau utangnya berasal dari bank konvensional, dan menjadikan akad murabahah setelah utang tersebut diambil alih. Namun BUS tersebut juga memberi peluang skim hiwalah ini kepada nasabah yang memiliki utang pada bank konvensional yang digunakan untuk modal kerja. Setelah itu, antara nasabah dengan Bank memakai akad musyarakah.

Skim musyarakah dalam fikih ekonomi termasuk ke dalam akad syirkah/partnership atau kerjasama dalam permodalan atau pengelolaan, atau merupakan salah bentuk skim investasi yang disyariatkan, dan hasil atau keuntungannya dibagi secara proporsional sesuai dengan kesepakatan antara sesama pemodal dan pengelola.

Cara yang dilakukan oleh Bank ini tentunya lebih memberi kesempatan lebih dibandingkan BUS sebelumnya dalam menyelamatkan nasabah dari bertransaksi dengan cara riba. Tentunya hal ini sangat dianjurkan dalam Islam.

\section{Gadai Emas}

Pelaksanaan gadai emas di dua BUS, sama-sama telah memakai tiga jenis akad, yakni Qardh (utang), Rahn (gadai), dan Ijarah (sewa/jasa). Namun perbedaannya terlihat, dari sisi ujrah yang dipungut dari nasabah akibat jasa pemeliharaan dan perawatan barang yang digadaikan. Kalau pada satu BUS ujrahnya dipengaruhi oleh masa yang dipakai selama perawatan tersebut, yakni Rp. 500,- per hari. Sedangkan pada BUS lainnya, perhitungan ujrah tersebut dipengaruhi oleh besarnya pembiayaan, yakni $1,25 \%$ x jumlah pembiayaan (qardh).

Ketentuan dalam Fikih Ekonomi tentang ketiga akad tersebut merupakan akad yang disyariatkan, sejauh sesuai dengan 
ketentuan yang telah digariskan dalam syariah.

Qardh, merupakan akad utang piutang yang memberikan nuansa tolong menolong. Hal ini tentunya sangat dianjurkan dalam Islam, sebagai firman Allah:

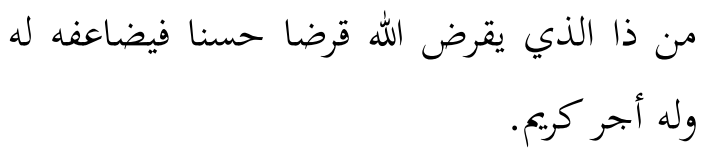

Siapa yang mau meminjamkan kepada Allah pinjaman yang baik, Allah akan melipat-gandakan (balasan) pinjaman itu untuknya dan ia akan memperoleh pahala yang banyak." (Q.S. al-Hadid [57] : 11)

Akad qardh ini dimaksudkan hanya untuk membantu dan memberikan kemudahan bagi orang yang dalam kesusahan, maka menurut Sayyid Sabiq, haram bagi yang memberikan pinjaman mengambil keuntungan, karena digolongkan ke dalam riba (Sayyid Sabiq, 1971: 147). Ketentuan ini juga berdasarkan kepada Hadis yang diriwayatkan oleh al-Harits bin Abi Usamah dari Ali R.a:

$$
\text { كل قرض جر منفعة فهو ربا. }
$$

Pada setiap transaksi utang piutang, terjadi pengambilan manfaat, maka hal itu tergolong kepada riba.

Dengan demikian, tidak tepat kalau Bank memungut ujrah-nya dari nilai pembiayaan, karena dapat dipahami mengambil keuntungan dari dana pinjaman (qardh) yang tergolong kepada riba, kendati menamakannya juga dengan ujrah. Ujrah sesuai dengan ketentuan Fikih Ekonomi, tentunya dimaksudkan adalah fee atau upah terhadap jasa diberikan, seperti merawat atau memelihara barang gadaian tersebut. Untuk itu cara yang lebih tepat memperhitungkan ujrah, yakni dengan memperhitungkan berdasarkan lama pemeliharaan (jasa) terhadap barang gadaian.

\section{PENUTUP}

Dari uraian data dan analisis di atas dapat disimpulkan bahwa perspektif Fikih Ekonomi dalam memandang berbagai akad tersebut, ada yang telah sesuai dengan ketentuan fikih, seperti mendahulukan akad wakalah dari pada murabahah, mengambil ujrah atas jasa pelayanan dalam skim talangan haji, bertransasksi murabahah dan atau musyarakah setelah pengalihan utang (hiwalah) oleh bank syariah, dan mengambil ujrah atas jasa pemeliharaan atau perawatan barang gadaian, seperti emas.

Namun ada juga yang tidak sesuai dengan ketentuan Fikih Ekonomi, seperti, memperhitungkan margin kepada jumlah pembiayaan oleh bank, bukan kepada harga barang di distributor, pada saat telah ada pengurangan urbun dari nasabah. Demikian juga halnya ada penghitungan ujrah dari jumlah pembiayaan gadai emas, pada hal itu adalah akad qardh (utang piutang).

\section{DAFTAR KEPUSTAKAAN}

Al-Baky, I'dad al-Syekh Zahir, t.th., Figh al-Mu'āmalāt li al-Imām Syaekh al-Islam Ahmad ibn Taymiyyah, Beirut: Dar al-Fikr al-'Araby. 
Al-Kahlani, t.th.. Subul al-Salam, j.3, Bandung: Dahlan.

Al-Misry, 'Abd al-Sami', 1991. alJām' fi Usūul al-Ribā, Damshiq: Dar al-Qalam.

Al-Qardawi, Yusuf, t.th. al-Ijtihād fi al-Syarì'at al-Islāmiyyāt, Kuwait: Dar al-Qalam.

Al-Sartar, Abd, 1406 H. al-Mu'āmalāt fi al-Islām, Dar al-Asfahany li alThaba'ah.

Al-Syarbasyi, Ahmad, 1987. alMu'jam al-Iqtiṣhād al-Islāmī. Beirut. Dar 'Alam al-Kutub.

Al-Zuhaily, Wahbah, 1989. al-Figh alIslamy wa Adillatuh, Damsyiq: Dar al-Fikr.

Antonio, Muhammad Syafi'i, 2001. Bank Syariah dari Teori ke Praktik, Jakarta: Gema Insan Press.

Bank Indonesia, 2003. Pedoman Akuntansi Perbankan Syariah Indonesia, Jakarta: Bank Indonesia.

Bank Islam Malaysia Berbatas, 1994. Islamic Banking Practice from the Practitioner's Perspective. Kuala Lumpur. BIMB.

Dewan Syariah Nasional MUI, 2006. Himpunan Fatwa Dewan Syariah Nasional, Edisi Revisi tahun 2006.

Direktorat Perbankan Syariah Bank Indonesia, 2011. Outlook Perbankan Syariah Indonesia.

Djazuli, A., dkk., 2002. Lembagalembaga Perekonomian Umat; Sebuah Pengantar, Jakarta: Rajawali Grafindo Persada.
Hasan, Ahmad, 1970. The Early Deveplopment of Islamic Jurisprudence, Islamabad: Islamic Research Institute.

Hasballah, 'Ali, 1971. Ushul alTasyri' al-Islamy, Mesir: Dar alMa'arif.

Ikhrom, Ahmad, dkk. 2001. alMadkhal li al-Fikr al-Iqtisādi fi alIslām, (terj), Jakarta: Zikrul Hakim.

Institut Bankir Indonesia, 2001. Konsep, Produk dan Implementasi Operasional Bank Syariah, Jakarta; Djambatan.

Kamal Khir, dkk. 2008. Islamic Banking, a Practical Perspective, Petaling Jaya: Pearson Malaysia Sdn. Bhd.

Karim, Adiwarman, 2006. Bank Islam: Analisis Figh dan Keuangan, Jakarta: Raja rafindo Persada.

Kasmir, 2004. Manajemen Perbankan, Jakarta: Raja Grafindo

Khan, Thariqullah \& Habib Ahmed, 2007. Risk Management, An Analysis of Issues in Islamic Financial Industry, Jeddah: Islamic Research and Training Institute.

Khir, Mohd. Kamal, dkk. 2008. Islamic Banking; A Practical Perspective, Petaling Jaya: Pearson Malaysia Sdn. Bhd.

Lewis, K. ,Mervyn \& Latifa M. Algaoud, 2003. Islamic Banking, (terj), Jakarta: Serambi Ilmu Semesta. 
Muhammad, 2002. Manajemen Bank Syariah, Yoryakarta: UPP AMP YKPN.

Nujaim, Ibn., Zayn al-Din ibn. Ibrahim, 970 H. al-Asybāh wa alNaza'ir 'alā Madzhabi Abì Hanifah al-Nu'man, Beirut: Dar al-Kutub al-'Ilmiyyah.

Sabiq, Sayyid, 1987. Fiqh al-Sunnah, Beirut: Dar al- Kutub al-'Araby.

Saeed, Abdullah, 1996. Islamic Banking and Interest, a Study the Prohibition of Riba and its Contemporary Interpretation, Leiden: E.J. Brill.

Sakti, Ali, 2007. Analisis Teoritis Ekonomi Islam, Jawaban Atas Kekacauan Ekonomi Modern, Paradigma\& Aqsa Publishing.

Syarifuddin, Amir, 1997. Ushul Fiqh, Ciputat: Logos Wacana Ilmu.
Syarifuddin, Amir, 2003. Garis-garis Besar Fikih, Jakarta: Prenada Media.

Syihata, Syauqi Ismail, 1987. Nazariyyat al-Muhasabah alMaliyah min Manzurin Islamy, Kairo: al-Zahrah li al-I'lam al'Arabi.

Triandaru, Sigit dkk., 2006. Bank dan Lembaga Keuangan Lain, Jakarta; Salemba Empat.

Wiroso, 2005. Jual Beli Murābahah, Yogyakarta: UII Press. 